Daniel R. Langton

Jewish Religious Thought, the Holocaust, and Darwinism: A Comparison of Hans Jonas and Mordecai Kaplan

The writings of two twentieth-century New York-based religious thinkers, Mordecai Kaplan and Hans Jonas, shared a common concern to find an alternative approach to the problem of evil in general and to the religious challenge of the Shoah in particular. For Kaplan, the founder of Reconstructionist Judaism, it was possible to draw upon his already well-developed, scientifically augmented (or inspired) revisions of the Jewish religion and the Jewish God. For the philosopher of technology, Jonas, the revisions to the traditional categories of Jewish theology arguably followed from his struggle to make some kind of moral sense of the Holocaust in the light of his interest in the biological emergence of selfhood. At the heart of the revisions of each, however, was a kind of cosmic evolutionism that necessitated an understanding of the origins of human ethics from an evolutionary perspective. While neither could be said to have demonstrated an intimate understanding of Darwinian theory (this is especially true of Kaplan), both viewed themselves as critically engaged with it and sought to utilize Darwin in offering accounts of a genocidal world that were neither entirely naturalistic nor entirely supernatural. 
Daniel R. Langton

\section{Jewish Religious Thought, the Holocaust, and Darwinism: A Comparison of Hans Jonas and Mordecai Kaplan}

\section{Introduction}

Mordecai Kaplan and Hans Jonas were two influential Jewish religious thinkers of the twentieth century who engaged seriously with scientific knowledge and, in particular, with Darwinism. By "Darwinism" is meant evolution by natural selection, a mechanism that emphasizes the elements of chance and competition in those directionless, natural processes that generate new species over time. For our purposes, the point is that these specific characteristics of Darwinism present a serious challenge to religious thinkers who would otherwise be willing to reconcile their theism with non-Darwinian conceptions of evolution or transmutation of organic life. Kaplan and Jonas are only two examples that might have been chosen from a number of Jewish thinkers engaging with evolutionary theory, Darwinian or otherwise, even if their interpretations of the God of Judaism were unusually radical and disquieting to many of their fellow Jews. ${ }^{1}$ What sets them

1 For two studies of Jewish engagement with Darwinism, which include treatments of

(C) Aleph 13.2 (2013) pp. 311-348 
apart, however, is that they applied their evolutionary-informed understandings of Judaism to Auschwitz, that is, to questions of morality after the Second World War. At the heart of their theories was a shared concern to explore the nature of divine action in the living world and to reconceptualize Judaism in an age of genocide by reference to the evolutionary origins of ethics, although they accomplished this in very different ways. Essentially, this is the justification for the present comparison of these two thinkers. It is by no means unusual to hear about the connection between the Holocaust and Darwinism; that is, the Holocaust as the product of the Nazis' obsession with social Darwinism and racist eugenics. However, the presentation that follows offers a very different picture of how Darwinism can be related to the Jewish experience, and to an understanding of the Holocaust itself.

\section{Mordecai Kaplan}

Let us begin with the Lithuanian-born, Conservative Jewish rabbi, Mordecai Kaplan (1881-1983). ${ }^{2}$ He was based for much of his career at the Jewish Theological Seminary (JTS) in New York and is probably best known as the founding father of the fourth Jewish denomination, Reconstructionist Judaism. ${ }^{3}$ Among the key influences upon his thought were the North American philosopher John Dewey, whose naturalist philosophy combined pragmatic humanism and religious terminology, and the French founder of sociology, Émile Durkheim, who argued from a naturalistic perspective that the origin and function of religion (as a body of beliefs and practices about the sacred) was to unify and maintain a society. His time at JTS-and his wider reception within American Jewry - was a troubled one, not least for the suspicion that his apparently naturalistic, pluralistic conception of God provoked and most famously because of his vision of Judaism as an evolving religious civilization that could be explained in purely natural terms. In large part, such views can be explained by the influence of evolutionary theory upon his thought. Kaplan's writings from the 1930s onwards manifest an interest in evolution in at least four different although related contexts.

First, evolution, in the sense of development or change, is used as a justification for Kaplan's reconstructionist project. As both an academic tutor and as a congregational rabbi, he became convinced that the current forms of Judaism, whether Orthodox or Reform or secular, had failed to satisfy the modern Jew. To such a Jew, the (neo-)Orthodox commitment to supernatural revelation at Sinai, the exclusivity of its revealed truth, and many of its pre-modern beliefs condemned it to obsolescence. On the other hand, the tendency of Reform Jews to replace the historical religion of Judaism that emerged organically from the Jewish national civilization with a universalist

both Kaplan and Jonas, see: Michael Shai Cherry, "Creation, Evolution and Jewish Thought” (doctoral dissertation, Brandeis University, 2001); Jewish Tradition and the Challenge of Darwinism, ed. Geoffrey N. Cantor and Marc Swetlitz (Chicago: University of Chicago Press, 2006).

2 For our purposes, Kaplan's key works are: Judaism as a Civilization: Toward a Reconstruction of American-Jewish Life (New York: Schocken 1967 [1934]); The Meaning of God (New York: Behrman's Jewish Book House, 1937); The Future of the American Jew (New York: Macmillan, 1948); Judaism without Supernaturalism. The Only Alternative to Orthodoxy and Secularism (New York: Reconstructionist Press, 1958); The Greater Judaism in the Making. A Study of the Modern Evolution of Judaism (New York: Reconstructionist Press, 1960); The Purpose and Meaning of Jewish Existence (Philadelphia: Jewish Publication Society of America, 1964); and The Religion of Ethical Nationhood: Judaism's Contribution to World Peace (London: Macmillan, 1970).

3 For biographical details see Mel Scult, Judaism Faces the Twentieth Century: A Biography of Mordecai M. Kaplan (Detroit: Wayne State University Press, 1993). 
religion, often reduced to ethical monotheism, left its conception of religion too dry and abstract. And, again, little spiritual satisfaction was to be gained by secular-cultural Jews who rejected religion altogether and who tended to rely upon secular nationalism for group solidarity. According to Kaplan, the solution was the position adopted by the so-called religious-culturalists, which, as Reconstructionism, would become the fourth Jewish denomination in the US. His functionalist approach sought to encourage interpretations and utilizations of the Jewish religious heritage that would ensure the creative social interaction required for a spiritually fulfilling community. ${ }^{4}$ The offer of an ethical worldview was a key to his program, but this had to be achieved without recourse to traditional, supernatural language or concepts. (We will set aside for the time being the tension in his nonsystematic writings, which allows scholars to read him variously as espousing naturalism, pragmatism, pantheism, and transnaturalism, and which suggest different stages in his thought, with an earlier naturalistic worldview later being compromised by a belief in a God, albeit one foreign to Jewish tradition.) As he would later put it, his "Judaism without supernaturalism" would be "a religion of ethical nationhood" (these being the titles of two of his later books). It will be important to bear these key two ideas of the centrality of community and the urgent need for a non-supernaturalist religion in mind as we proceed. In any case, the result was a historical reconstruction of Jewish civilization as an evolving phenomenon. He identified several radically different stages of its past development, including the Prophetic, henotheistic period, which was largely syncretistic in character; the theocratic period of the Second Commonwealth, which was focused mainly on the Temple and the Torah; and the so-called "other-worldly stage," which, after the destruction of the Temple, comprised the development of a rabbinic religion that continued to evolve for the next two millennia. Rather than look for continuity in Jewish religious ideas or precepts, which were almost unrecognizable from period to period,
Kaplan asserted that continuity was to be found in the life of the Jewish people themselves. For him, such developments suggested a living organism transforming and adapting to its changing environment. For Kaplan, then, Jewish religion has always and will always evolve. Existing forms are inadequate; Reconstructionism is required to resolve supernaturalism for the modern individual and for a spiritually fulfilling group identity.

Second, evolution is presented as a divine process or principle that brings order out of chaos. To understand this, one needs to understand the concept of transnaturalism, which was central to the reconstructionist project. Kaplan was against supernaturalism insofar as it created a dichotomy of natural and supernatural realms. Especially offensive to the modern mind was the supernaturalist idea of a personal God who exists outside the natural world and is not subject to the laws of nature. On the other hand, he was dissatisfied with naturalism, defined as a methodological assumption that legitimate knowledge is obtained via reason and critically analyzed experience, or via inference from observation. Strict naturalism was inadequate for Kaplan because it was incapable of dealing with the phenomena of mind, personality, purpose, ideals, values, and meanings, which, traditionally, have been derived from revelation-based or supernatural forms of religion. Kaplan sought to develop a philosophical theology that avoided the pitfalls of both supernaturalism and reductive naturalism. The solution was "transnaturalism," which was in part an attempt to justify belief in transcendent value and meaning in natural terms rather than supernatural terms. How did he hope to do this? It required some interesting redefinitions of familiar categories.

In Kaplan's worldview, nature was not defined as the totality of being; instead, it was conceived of as a state of chaos, with disorder

4 Kaplan, Judaism as a Civilization, pp. 311-331. 
regarded in negative terms as a destructive evil. There was a principle at work in the universe that brought order out of this chaos, and this was regarded in positive terms as a creative good. This ordering principle, this creator of order, is defined as God. As Kaplan expressed it, "Nature is infinite chaos, with all its evils forever being vanquished by creativity, which is God as infinite goodness." ${ }^{5}$ Or as he put it elsewhere:

the fact is that God does not have to mean to us an absolute being who has planned and decreed every twinge of pain, every act of cruelty, every human sin. It is sufficient that God should mean to us the sum of the animating, organizing forces and relationships which are forever making a cosmos out of chaos. This is what we understand by God as the creative life of the universe. ${ }^{6}$

Thus the universe is not some kind of inanimate mechanism. Inherent in it is an animating process that makes progress possible. There is no hint here that the directing of the process is external to the universe, since God is defined as a natural, progressive evolutionary process rather than as a supernatural personal deity. If the God-idea continued to function as it always had, then this was a natural phenomenon that could adequately ground transcendent value and meaning. ${ }^{7}$ Existence was not meaningless, because there was a direction and a sense of purpose identifiable within nature. Kaplan's theory of transnaturalism as presented here is very abstract at the cosmic level but is less so at lower levels of organization, such as at the level of humanity.

This brings us to the third way in which Kaplan discussed evolution, that is, in terms of the biological evolution of mankind. Kaplan did not spend a lot of time on evolutionary theories of organic life per se, but he was interested in human evolution. Cherry has noted that Kaplan does not explicitly relate human evolution to Darwinian natural selection but rather always talks of descent from animals; ${ }^{8}$ Swetlitz has presented
Kaplan as believing that "animal evolution is directed by natural selection and leads to adaptation to particular environments, whereas human evolution is directed by intelligent choice and is characterized by adaptability." " But Kaplan's view is slightly more complicated than these comments suggest. The evolution of plant and animal life, including human life, by means of Darwinian natural selection was a given, as far as Kaplan was concerned, although there is no doubt that in his mind natural selection was inadequate to explain human evolution in its entirety - or, at least, those aspects of human evolution that Kaplan was most interested in, namely, the ethics of a community. This led him to develop his theory of "spiritual selection," which added a complementary-and competing-force for selection to the mix of evolutionary pressures that shaped human evolution, including natural selection and sexual selection. Kaplan inferred the reality of "spiritual selection" from his observation of human history. What was his evidence and what, exactly, is this "spiritual selection"?

For Kaplan, human evolution is ongoing and appears to possess direction. ${ }^{10}$ Specifically, he suggests that "the course of human history shows that the human race is moving in the direction of enhanced personality and enhanced sociality." 11 Not only is human nature

5 Kaplan, The Religion of Ethical Nationhood, p. 51.

6 Kaplan, The Meaning of God, p. 76.

7 Ibid., p. 29.

8 Cherry, "Creation, Evolution and Jewish Thought," p. 233.

9 Marc Swetlitz, "Responses to Evolution by Reform, Conservative, and Reconstructionist Rabbis in Twentieth-Century America," pp. 47-70 in Cantor and Swetlitz, Jewish Tradition and the Challenge of Darwinism, on p. 54.

10 Kaplan, The Religion of Ethical Nationhood, pp. 105, 108.

11 Kaplan, The Meaning of God, p. 122. See also Kaplan, Judaism as a Civilization, p. 477. 
improving, there is reason to hope that it will progress so far that man becomes "a higher kind of creature." 12 Since an increasingly moral society is, in effect, an increasingly ordered society, Kaplan would argue that we can trace the imprint of the cosmic-principle-that-makes-fororder, or God, in the history of human society. And while he accepts that he cannot prove that the progressive trend in the development of human nature will continue, Kaplan suggests that, based on past experience, it is not an unreasonable hypothesis. ${ }^{13}$ What Kaplan wishes to stress, however, is that humans differ from all other forms of life in that they are partners with God in determining the direction of their ethically progressive evolution. As he puts it,

Unlike other living creatures [man] must take a hand in his own metamorphosis. He must consciously and deliberately share in the cosmic or divine process which impels him to become fully human. ... Such creative freedom fulfills the Judeo-Christian doctrine that man was made in the image of God...14

Evolution depends upon adapting to changing environments. Humans can partially determine their evolution precisely because, unlike nonhuman species, they can radically shape their environment, whether physical, social, or cultural. Consequentially, the potential for evolutionary change is much greater for humans than for other lifeforms. ${ }^{15}$ How do human beings alter their environment? For Kaplan, a big part of this story is the emergence of group religion. He points to the widespread cultural aspiration throughout history to look beyond the limitations of current human life towards a better future, and the many religious sources that bear on the human penchant for seeking for self-improvement. For example, despite the Bible's recognition that "there is none so righteous on earth as not to sin" (Eccles. 7:20), its authors longed for "the advent of the perfectly righteous man": "Behold the days are coming, says the Lord, when I will raise up for
David a righteous branch and he shall reign as King and deal wisely, and shall execute justice and righteousness in the land" (Jer. 23:5-6). ${ }^{16}$ Particularly relevant here was the idea of paradise in the afterlife. ${ }^{17} \mathrm{He}$ also emphasizes the survival value of a coherent society in contrast to one left in the state of nature; it is clear to him that religion functions as a driver for moral order and thus for coherence in society.

If we analyze the evident fact that the human species evolved from savagery to civilization through the operation of the social instinct, we find that those groups or cultural units survived in which the individual learned to consider his personal existence less valuable than the existence of the group. This habit of behavior without which civilization is inconceivable, has been bred into the very substance of the mental life of humanity by religion. ${ }^{18}$

And again,

This new development in group religion marks the latest stage in the evolution of man. To achieve salvation man must synthesize his selfhood and otherhood.... The capacity to play a conscious role in his own evolution is man's prerogative. Such creative freedom fulfills the Judeo-Christian doctrine that man was made

12 Kaplan, The Religion of Ethical Nationhood, p. 108.

13 Ibid., p. 133.

14 Ibid., pp. 103-104, 104-105. See also Kaplan, The Meaning of God, p. 123.

15 Kaplan, The Religion of Ethical Nationhood, p. 109.

16 Ibid., pp. 111-112.

17 Ibid., p. 108

18 Kaplan, Judaism as a Civilization, p. 334. 
in the image of God. ... The art of living requires the interaction of a harmonious personality and a cooperative society. Group religion should help man to play a conscious role in his own evolution, to elect self-metamorphosis as his destiny. ${ }^{19}$

As far as Kaplan was concerned, the fact that the history of religion was littered with redundant beliefs and behavior that would not be acceptable in the modern world did not undermine the claim that religion had acted as a powerful civilizing force over the millennia. ${ }^{20}$

While Kaplan is confident that humanity is progressing, he cannot be sure of the actual achievement of what he believes is possible, that is, some kind of moral perfection. In addition to the divine force that makes for order and humankind's best aspirations (as combined in group religion, which seeks to sensitize individuals to their responsibilities to a wider society), the old, atavistic forces of man's bestial past act as a powerful brake. ${ }^{21}$ But, as Kaplan views it, the hope lies in humankind's ability to recognize this reality and work to overcome it. ${ }^{22}$ From all this it should be clear that for this particular thinker Darwinian evolution might explain the beginnings of man, but not his destiny; humankind's evolution will be determined by humankind itself as long as it works in harmony with the cosmic force that makes for order and remains conscious of the threats to progress posed by the inherent weaknesses of humankind that result from its bestial origins. In this way, Kaplan's transnaturalist religion offers a vision of God acting, at least in part, as a metaphor for buman evolution ("Transnaturalist religion beholds God in the fulfillment of human nature and not in the suspension of the natural order"). ${ }^{23}$ The mechanism to effect this evolutionary path of socio-ethical progress is what Kaplan calls "spiritual selection."

For Kaplan, "spiritual selection" is the evolutionary process or law that relates to progress, especially in the context of the development of a civilizing, morally ordered society. It represents a kind of harmonization with the principle of moral order that exists more generally in the cosmos (an assumption of many in the ancient world, including the Stoics and especially the Hebrews). ${ }^{24}$ This "spiritual selection" is explicitly contrasted by Kaplan with natural selection, which generated the raw material from which the human is composed, but from which the human is now freed, at least potentially. ${ }^{25}$ As he explains it,

The term "natural selection" is descriptive of the process by which certain species are able to survive. The term "spiritual selection" may, therefore, be used to describe the process that makes for the survival of human beings. The Ten Commandments, the moral and spiritual laws in action, represent the process that makes for buman survival and salvation. ${ }^{26}$

It is a concept that is basic to Judaism; alongside "spiritual selection," Kaplan identifies Faith, Hope, Humility, Inner Freedom, Patience, Thankfulness, Justice, and Love as "basic values in Jewish Religion." 27 In fact, although Kaplan did not make this explicit, one might see the idea of "spiritual selection" as the generalization of the special case of the doctrine of the election of Israel. According to Kaplan, the doctrine of the chosenness of the People of Israel had shaped the Jews as a nation. In functional terms, a nation was "the most potent

19 Kaplan, The Religion of Ethical Nationhood, pp. 104-105.

20 Ibid., pp. 110-111.

21 Ibid., pp. 101-102.

22 Kaplan, The Meaning of God, pp. $135 \mathrm{ff}$.

23 Kaplan, Judaism without Supernaturalism, p. 10.

24 Kaplan, The Future of the American Jew, p. 248.

25 Ibid., p. 247.

26 Ibid., pp. 247-248.

27 Ibid., chapter 15 
social force in human society" insofar as it could bestow a profound sense of collective purpose and meaning and, specifically, insofar as it inculcated a collective future hope. It was in large measure the fact that "the Jewish consciousness was always employed in the contemplation of the future" (expressed as "the messianic ideal and the vision of a better world") that had facilitated their "power of endurance" down through the centuries. From this perspective, the "moral and spiritual powers" of Jewish nationhood had made it a highly effective survival unit for Jewish society. ${ }^{28}$ "Spiritual selection" is also a concept that is quintessentially transnaturalist, in that it can be expressed in natural or supernatural language, though neither is quite adequate.

Whether one thinks of spiritual selection as operating through human reason, or as operating through norms held to be supernaturally revealed, as in the Judeo-Christian tradition, its acceptance is a challenge to innate impulses and desires. It demands that these be tamed and brought under control. The physical appetites for food and sex gratification, the derivative drives for power, acquisition, glory, all the sadistic impulses born of the conflicts into which these interests have led men and their pre-human ancestors before them-all these need to be checked, controlled and brought into a pattern of integrated personality and cooperative society, if the conditions of spiritual selection are to be met.

Our sages identified these tendencies that needed to be tamed and controlled as the yezer hara or evil inclination, and they very significantly equated this evil inclination with Satan and the Angel of Death [B Bava Batra 16a]. ${ }^{29}$

He goes on to suggest that salvation "may be conceived as a deliverance from the power of these satanic tendencies that operate in the human personality and in human society," 30 that is, the ordering of the disruptive forces. The societal aspect and the egalitarian principles are fundamental. ${ }^{31}$ While some might deny it, Kaplan argues that what is essentially a commitment to the love of one's neighbor could release man from the grasp of natural selection. ${ }^{32}$

So, just as the disorder and chaos of the universe are in a process of becoming ordered and coherently related, the same progressive principle is at work in human life. Human history demonstrated a direction and a sense of purpose in relation to an ever-growing sensitivity to morality and to the development of an ethical, intersocial life. It is worth noting that in propounding his theory of "spiritual selection" and the role of religion for human or societal evolution, Kaplan demonstrates no awareness that Darwin himself had argued for the evolution of ethics as advantageous for the survival of the group in The Descent of Man (1871). ${ }^{33}$ More generally, Kaplan's insistence on an ethical direction differentiates "spiritual selection" from a truly directionless Darwinian evolutionary process. In fact, he is quite inconsistent in his presentation of Darwinism. At times it appears acceptable to him if it can be understood in his terms as a scientific theory that studies sequences of phenomena (that is, it describes), but does not seek to give them meaning (that is, it does not explain), and insofar as Darwinian evolution is understood to have been initiated by God and is progressive in character, and insofar as the directive force behind this is divine in the sense of generating order. At other times, as

28 Kaplan, Judaism as a Civilization, pp. 253, 262-263.

29 Kaplan, The Future of the American Jew, p. 249.

30 Ibid

31 Ibid., p. 254

32 Kaplan, The Future of the American Jew, p. 253.

33 Charles Darwin, The Descent of Man, and Selection in Relation to Sex (London: J. Murray, 1871), p. 166 
emphasized here, it is presented much more negatively and in contrast to "spiritual selection." In particular, his conception of evolution has a direction and feels a lot closer to a Lamarckian theory, a kind of use-itor-lose-it conception of the moral sense. One might also compare his approach to Herbert Spencer's, in his disinterest in the ultimate cause of evolution and his focus on the meaning and purpose of evolution instead. In the end, Kaplan's interest in the biological evolution of humankind comes down to an analysis of the origins and development of moral freedom.

Fourth, Kaplan discusses evolution in relation to what we would now call Social Darwinism, that is, the application of a theoretical framework for organic biology to human society, and in particular the Nazi theory of race competition. Kaplan, as one might expect, is hostile to such ideologies, but his key reason is that they threaten to undermine his understanding of humans as partners with the divine in bringing meaning and order to the universe. In this context, he acknowledged that following the Enlightenment's realization that man cannot be regarded as the sole purpose of creation and discovery of the close similarities between animals and men, "the greatest encouragement to revolt against the restraints of reason and morality came with the discovery by Darwin of the principle of natural selection." Darwin himself is not blamed for this, but rather Nietzsche and others who championed competition, denial of the moral categories of good and evil, and the usurpation of power. ${ }^{34}$ Ultimately, the logic of Social Darwinism as made manifest in the Holocaust demonstrated the destructive power of this aspect of evolutionary science. ${ }^{35}$ Kaplan explicitly identifies Hitler as the embodiment of those who would champion "the brutal and irrational elements of human nature," arguing that he went about it "by cunning manipulation of all the diabolic forces at work in modern society." 36 The glorification of war and the emphasis of human inequality that resulted from a particular interpretation of natural selection were also vital to the Nazi project: ${ }^{37}$
The ideology of fascism not only accepted as normal and desirable such inequalities as existed among men, but it deliberately conjured up imaginary inequalities for the sake of creating actual inequalities where none existed. It trumped up false theories about strong and weak races, and declared the former must become master races and the latter slave races. ${ }^{38}$

Primarily because such an ideology threatened the progress of spiritual selection, he was implacably opposed to the widespread evils of racial science and the suffering that were characteristic of it, as a glorification of a pseudo-scientific interpretation of Darwinian natural selection. As he himself put it,

Natural selection exalts inequality as a creative principle in human life, whereas the doctrine of spiritual selection sees in the effort to establish equality among men through just laws and the exercise of compassion and kindness an evidence of divine creativity. What differentiates man from the beast is that his nature not only makes for the survival of the fittest, but aims to make the greatest possible number fit to survive. ${ }^{39}$

Thus, Swetlitz is partially correct to say that, when considering the Holocaust, Kaplan's complaint was not the destructive impulses inherited from animal ancestors, but rather the ideologies that removed

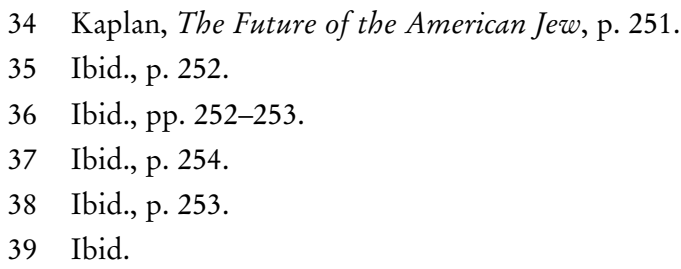


the constraints of reason and morality and let loose bestial impulses. ${ }^{40}$ But Kaplan does not denounce the Holocaust solely in relation to ideology. He also recognizes that it must be engaged with theologically, that is, engaged with as a moral evil. After offering a cautionary note concerning the danger of exaggerating the extent of evil in the world in $\mathrm{dwelling}$ too long on the Nazi genocide, he continued:

This [concern not to exaggerate evil in the world] does not mean that we lose sight of the evil in the world. It merely means that we do not permit it to represent for us the essential and ineradicable nature of reality, in whole or in part. We identify the good that we have experienced with that which ought to be, with that we intend, so far as in our power lies, shall be; while the evil becomes identified with what ought not to be and with what we intend, so far as in our power lies, to abolish. The achievement of the good expresses for us, therefore, the direction of our life's current, while the evil appears as an obstruction which resists the current, but cannot stop it. ${ }^{41}$

After defining evil as that which "ought not to be," Kaplan asserts:

This deliberate focusing on the good confers on our contemplation of the good the power of making us will the abolition of the evil, while our refusal to focus attention on the evil deprives it of that fascination which enables it to inhibit our pursuit of the good. ${ }^{42}$

Katz has complained that, if we bear in mind that Kaplan was writing after the Shoah, his assertion that evil can be defined as what "ought not to be" and that it might be abolished by "focusing on the good" beggars belief. ${ }^{43}$ How, Katz asks, could Kaplan maintain such a view when confronted with the reality and the scale of human suffering during the Holocaust? To decide whether or not Katz's criticism is valid, it is necessary to review briefly Kaplan's approach to the problem of evil more generally, as presented in his writings before the Shoah, and to provide some contextualization from our earlier consideration of his engagement with evolutionary theory.

In the prewar context, Kaplan's key concern had been how Jewish religion could free itself from the ancient chains of the problem of evil. He had begun by arguing that the idea of justifying God in relation to the problem of evil was "self-contradictory." Because of the subjective reality of evil and the fact that one experiences evil as evil, even though from some more objective perspective one might regard the apparent evil as a means to a greater good, then such traditional theodicies could not avoid presenting God as the author of means that are evil. If subjective experience is taken seriously, no divine perspective can render an evil experience as only apparently evil. ${ }^{44}$ The challenge remains for modern forms of Judaism, too, in that they likewise fail to explain evil, that is, they fail to help us adjust constructively to the evil in ourselves and in the world. ${ }^{45}$ Kaplan's functionalist position is that one cannot deny the existence of evil (or goodness) in the world, and yet one has no means by which to integrate it satisfactorily into a coherent worldview or theology. ${ }^{46}$ The minimum that one needs from religion, he suggests,

40 Swetlitz, "Responses to Evolution," p. 57.

41 Kaplan, The Future of the American Jew, p. 236.

42 Ibid.

43 Steven T. Katz, “Mordecai Kaplan's 'Judaism as a Civilization': The Legacy of an American Idea," Jewish Social Studies 12 (2) (2006): 115-126, on p. 123

44 Kaplan, The Meaning of God, p. 72.

45 Kaplan, Judaism as a Civilization, pp. 115-116.

46 Kaplan, The Future of the American Jew, pp. 235-6. Katz has pointed out that Kaplan is not entirely consistent on this point and elsewhere does appear to negate the reality of evil. See Katz, “Mordecai Kaplan’s 'Judaism as a Civilization’,” p. 117. 
is the conviction and assurance that evil is not absolute and final, and that justice will be triumphant.

All that religion calls upon us to believe is that the element of helpfulness, kindness and fair play is not limited to man alone but is diffused throughout the natural order. It asks us to obey the moral law in order that we may call to our aid those forces in the world which make for human life and its enhancement. We cannot claim to comprehend why evil should be necessary in the process of world making and development. But in affirming the existence of God, we deny to evil the nature of absoluteness and finality. The very tendency of life to overcome and transcend that evil points to the relativity of evil. As life progresses, the tendency is increasingly reinforced and organized, resulting in the growth of man's power to eliminate, transform or negate the evil in the world. ${ }^{47}$

Notice here the optimistic claim that moral order can be traced as "diffused throughout the natural order" and that the power of evil is diminished by the tendency of life to progress in such a way that man can increasingly "eliminate, transform or negate the evil in the world." How, then, does Kaplan define evil (as a subjective reality)? In essence, evil was that which is not yet ordered by human intelligence, or the "energy" or "force" acting within the natural world to produce that which "renders human life worthwhile." ${ }^{48}$ Evil is a disorder and a purposelessness in human life, in history, and in the world, which can be rectified only by the creative, willful act of asserting meaning and order. ${ }^{49}$ Acknowledging that we cannot know why evil (or disorder) is a necessary constituent of reality, one can avoid the pitfalls of the traditional conception of God as the personal author of evil and suffering, one way or another, by redefining divinity as the creative force in the universe that ultimately brings order out of chaos. ${ }^{50} \mathrm{~A}$ religion that could argue thus would be a religion that would be free of the problem of evil, because it would no longer need to deal with an omnipresent, omnipotent, omnibenevolent personal deity. ${ }^{51}$ And it is worth noting that in Kaplan's mind this solution applied as much as to the natural world as to human experience (although this has been criticized as nonsensical by Katz, inasmuch as natural disasters can hardly be the responsibility of a nonpersonal deity). ${ }^{52}$

That was how Kaplan saw the problem of evil in the late 1930s. (Thus Swetlitz is obviously wrong to claim that Kaplan had previously related the aggressive and competitive side of human nature to human evolution and that only in the 1940s did he focus attention on the problem of evil. ${ }^{53}$ According to Katz, nothing much changed in Kaplan's approach after the Shoah. That, of course, is the precisely the problem, for then it seemed almost offensive to maintain such an optimistic, naive view of evil. Is this a fair critique? On the one hand it is true that Kaplan did not discuss the problem of evil and suffering very differently from how he had done so before the war. But, arguably, this is not the problem that a critic such as Katz would suggest. As discussed earlier in relation to Kaplan's conception of "spiritual selection," Kaplan has a view of evil at the cosmic level as a

47 Kaplan, The Meaning of God, pp. 75-76.

48 Ibid., p. 133

49 Ibid., pp. 67-72.

50 Kaplan, The Meaning of God, p. 76

51 For a comparison of Whitehead and Kaplan on this, see William E. Kaufman, The Evolving God in Jewish Process Theology (Lewiston, NY: Edwin Mellen Press, 1997), p. 84.

52 Kaplan, The Meaning of God, p. 76. Katz, "Mordecai Kaplan's 'Judaism as a Civilization'," p. 119

53 Swetlitz, "Responses to Evolution,” pp. 54-55. 
kind of structural disorder and at the human level as a kind of moral disorder and social disharmony. At the human level, violence can be understood as a throwback to atavistic impulses that originate in our animal ancestry. It is striking, though, how often cosmic evolution and human evolution are conflated in Kaplan's thought. It seems too simplistic, then, to focus, as Katz does, only on Kaplan's talk of evil at the cosmic level, which is highly abstract, and which appears entirely inadequate in the face of the human cost of the Holocaust, and the enormity of the suffering of those tragically caught up in it. One should not read Kaplan's definitions of evil as what "ought not to be" or his admonition to continue "focusing on the good" without regarding them as abbreviated shorthand for much richer conceptions. Kaplan's frequent and repeated discussions of "spiritual selection" as a force for moral development away from our animalistic origins needs to be taken into account in any discussion of his theological engagement with the Shoah. He approaches the moral evils of the Nazi genocide in evolutionary terms, that is, as the result of our tragic failure to follow the logic of "spiritual selection" and align ourselves with the (divine) force for cosmic order and to free ourselves from the bestial impulses of our animal ancestry. It is an account of morality that grounds the issues in a naturalistic theory of human nature and in a more abstract metaphysical theory of the structure of reality. Furthermore, the Holocaust did bring about a new element in Kaplan's thought about morality, as we have seen in his passionate critique of Social Darwinism as one of the roots of the human evil of the Holocaust. Thus one should not regard Kaplan as a hopeless optimist, as Katz seems to do. Kaplan certainly advocates that we not forget or ignore the improving ethical trajectory of human society in history, but he is also ever ready to admit that such historical advances in morality hang by a thread and are all too easily set back by the kind of ideologies proffered by the Nazis. In this context, Katz is also a little unfair to overlook Kaplan's critique of Social Darwinism.

\section{Hans Jonas}

Let us now move to Hans Jonas (1903-1993), ${ }^{54}$ the German-born historian of religion, philosopher of technology, and theologian, who was also based in New York for much of his career, at the New School for Social Research. Jonas' studies before he came to biology are important for understanding some of the ideas he espouses, including self-autonomy and the search for an objective foundation for morality. It is surely highly relevant that these included a book on the problem of freedom in Pauline thought, and another book on Gnosticism and Gnostic concerns about how to free the spirit from matter, and that he was disillusioned by his teacher, Heidegger, whose embrace of Nazism he famously denounced as lacking an adequate ethical core. ${ }^{55}$ From the 1950s onwards, Jonas set himself the goal of developing an ethical system that was, in principle, free from divine or supernatural

54 For our purposes, Jonas' key works are: Hans Jonas and Lawrence Vogel, Mortality and Morality: A Search for the Good after Auschwitz (Evanston, IL: Northwestern University Press, 1996), portions of which were presented as public lectures or published earlier, mostly from the 1980s, but a few as early as the 1960s; Hans Jonas, The Phenomenon of Life: Toward a Philosophical Biology (Evanston, IL: Northwestern University Press, 2001 [1966]), German original: Hans Jonas, Organismus und Freibeit: Ansaetze zu einer Philosophischen Biologie (Göttingen: Vandenhoeck \& Ruprecht, 1973), portions of which were presented as public lectures or published earlier, mostly in the 1950s and 1960s; Hans Jonas and David Herr, The Imperative of Responsibility: In Search of an Ethics for the Technological Age (Chicago: University of Chicago Press, 1984), German original: Hans Jonas, Das Prinzip Verantwortung: Versuch Einer Ethik für die Technologische Zivilisation (Frankfurt am Main: Insel, 1979).

55 For biographical details, see Christian Wiese, The Life and Thought of Hans Jonas: Jewish Dimensions (Waltham, MA and Hanover NH: Brandeis University Press, 2007), pp. 20-21. 
authority. Like Kaplan, he recognized that for many people the religious basis of morality had been powerfully undermined by the successes of the natural sciences, with the result that modern society had lost its ethical bearings in a sea of moral relativism. Unlike Kaplan, Jonas came to believe that he could derive an alternative foundation for an ethical system from the science of biology. ${ }^{56}$ His approach, broadly speaking, was to speculate on the meaning and values one might derive from what was known about nature in general, and the evolution of life in particular, in such a way that these speculations absolutely did not contradict scientific knowledge but were rigorously and logically compatible with it. There was no good reason, he argued, why one needed to stop at the purely naturalistic methodology of science, as if only materialist or reductionist interpretations of the science were valid. ${ }^{57} \mathrm{He}$ wanted to explore the moral and metaphysical meaning of scientifically observed phenomena, even if, or because, one could no longer depend upon religious authority to supply it. As will be seen, his work on metabolism and on certain biological drives found in all organisms led him to view life itself in relational terms and to endow it with ethical meaning. ${ }^{58}$ Later, in an apparently unrelated meditation upon the moral catastrophe of the Shoah, Jonas realized that his philosophical reflections about evolutionary biology had made it possible for him to explain the apparent absence of God at the time. Jonas did not regard himself as a theologian, but this synthesis of biology and Jewish religious concerns means that his theological speculations are of greatest interest for our purposes. Somewhat unfairly, Jonas has been marginalized in both twentieth-century Jewish thought and the philosophy of biology, partly because he provoked suspicion by attempting to bring together the two spheres of thought, but more importantly because of the way he understood and applied evolutionary theory, as we shall see. For biologists, he seemed to offer only a partial comprehension of Darwinian evolutionary theory; for religious Jews, his God was disconcertingly paradoxical and unfamiliar, despite his best efforts to relate his ideas to Jewish tradition.

A useful starting point is Jonas' reflections on biology and his understanding of evolution. In fact, Jonas regarded Darwinian evolution by natural selection as only one instance of a more general principle of evolution, such that the very universe we inhabit was best understood as the product of evolutionary processes. (There are some similarities here with Kaplan's ordering principle.) Jonas argued that we find ourselves in a lawful, ordered universe precisely because any unlawful, disordered universes would not have been stable enough to produce life. As he put it,

The laws of nature arose through the emergence-also in the midst of disorder-of stable, relatively long-lasting realities that behave always (or for a very long time) in the same way and thus succeed. Here we have the most primordial and fundamental instance of "the survival of the fittest." Order is more successful than disorder. ${ }^{59}$

56 Hans Jonas, "Is Faith Still Possible? Memories of Rudolf Bultmann and Reflections on the Philosophical Aspects of His Work," pp. 144-164 in Jonas and Vogel, Mortality and Morality; first published as Hans Jonas, "Is Faith Still Possible? Memories of Rudolf Bultmann and Reflections on the Philosophical Aspects of His Work," Harvard Theological Review 75 (1) (1982): 1-23. See also Hans Jonas, "Epilogue: Nature and Ethics," in Jonas, The Phenomenon of Life, p. 284.

57 Jonas, The Phenomenon of Life, p. xxiii.

58 Arguably, this approach was also influenced by his study of Gnosticism. See the Editor's Introduction in Jonas and Vogel, Mortality and Morality, pp. 7, 9.

59 Hans Jonas, "Matter, Mind, and Creation," pp. 165-97 in Jonas and Vogel, Mortality and Morality, on p. 168; first published (in abbreviated form) as "Mind, Nature and Creation," Scheidewege 18 (1988): 17-33. 
The universe develops and evolves because there is always some disorder within it, and this disorder throws up accidental or random structures and events on which natural selection can act, thereby leading to evergreater levels of order. ${ }^{60}$ This principle-that order emerges from disorder through a kind of natural selection-explains how it was that the laws of nature acting upon the world of matter eventually gave rise to life, since, from a certain perspective, life simply represents the latest stage in a series of ever more sophisticated arrangements of matter. But for Jonas, close observation of the fundamentals of biology suggested that life was actually a good deal more than just a highly complex, mechanistic ordering of matter.

The observed biological phenomenon with which Jonas was primarily concerned was metabolism, that is, the biological process by which an organism exchanges matter with the environment. ${ }^{61} \mathrm{He}$ was fascinated by the relationship between a living organism and the materials that surrounded it. As he explained, the substance of the organism is continually replaced, as matter from outside of itself is taken in, absorbed, transformed and expelled. As a metabolizing system, an organism can be neither entirely distinguished from its environment nor entirely identified with the matter from which it was composed, since it and environment are in constant intercourse over time. Rather than speak of a living body as a static and unchanging unit, one should regard it as a dynamic, ever-renewing pattern of selforganizing matter, something he described as "a transcending form" or "an event structure." ${ }^{62}$ Or one might put this another way, as Jonas himself did: the organism is in a dialectical relationship to matter. It is both dependent upon matter for its substance and independent of matter in the sense that its functional identity does not coincide with the substantial identity of its material components. With organic life, matter had taken on a revolutionary new mode: matter could now be more than just matter. The emergence of the phenomenon of metabolism represented the moment that matter had in some profound sense freed itself from the constraints of matter. ${ }^{63}$ Jonas' way of describing this quality of an organism's matter as more-than-the-sumof-its-parts was to say that the organism possesses an inner identity that gives it a unity despite the constant turnover of its constituent parts - what he called "the dimension of the subjective." ${ }^{64} \mathrm{He}$ saw this "concept of the self" 65 or "subjective inwardness" 66 as unavoidable when describing even the most elementary instances of life. ${ }^{67}$ Such primitive life-forms were "egocentric," insofar as each demonstrated an absolute interest in its own being and continuation. ${ }^{68}$ Having said this, Jonas argued that it was with the eventual arrival of higher animal life via the evolutionary processes of natural selection that a quite different order of selfhood was achieved. An animal that can move, perceive, and feel in real time will achieve a differentiation of self to a profound degree because it will, by necessity, have to distinguish constantly between itself and the complicated world with which it must engage in so many different ways. ${ }^{69}$ Not surprisingly, Jonas' account of the

60 Jonas credited this observation to Darwin ("Matter, Mind, and Creation," p. 169).

61 Hans Jonas, "Evolution and Freedom," pp. 59-74 in Jonas and Vogel, Mortality and Morality, on p. 64; first published as Hans Jonas, "Evolution und Freiheit," Scheidewege 13 (1983-4): 85-102.

62 Ibid., pp. 64-65.

63 Ibid., pp. 66-67.

64 Ibid., pp. 66-67.

65 Ibid., p. 67.

66 Hans Jonas, “The Burden and Blessing of Mortality,” pp. 87-98 in Jonas and Vogel, Mortality and Morality, on p. 92; first given as a public lecture of the same title at the Royal Palace Foundation in Amsterdam, 1991.

67 Jonas, "Matter, Mind, and Creation," p. 169.

68 Jonas, "Evolution and Freedom," p. 69

69 Ibid., pp. 70-73. 
natural history of freedom (that is, the freedom of matter from itself) leads up to humanity, a species that has leaped ahead of all other animals with imagination and art and self-reflective thought. (In particular, Jonas identifies the decisive human qualities as symbolized in the tool, which represents a kind of mastery of matter, in the image, which represents the capacity to create nonmaterial worlds of the imagination, and in the grave, which represents the faith or belief that the world is more than mere matter). ${ }^{70}$

It would, however, be a great mistake to see Jonas arguing thus as if he were concerned to restore the dignity of mankind in a postDarwinian world by reinstating humanity at the top of the tree of life, vastly superior to the rest of life. In fact, and here there is a clear difference with Kaplan, Jonas was very much concerned with the nonbuman biological realm and the need to accord it the dignity it was due. He regarded this as Darwin's key contribution:

The affront to human dignity posed by the [Darwinian] theory of man's descent from animals provoked outrage, but this reaction overlooked the fact that the same principle restored a degree of dignity to the phenomenon of life as a whole. If man is related to the animals, then the animals are also related to man and therefore, in degrees, possess that inwardness which man, their most highly advanced relative, is aware of in himself. ${ }^{71}$

Even while acknowledging humankind's distinctive qualities, throughout his writings Jonas emphasized the continuity between the most primitive and the most complex forms of life; from the time of its initial emergence, organic life has demonstrated a tendency towards ever more sophisticated modes of cultivating the self and freedom. There is no obvious explanation for why it should have done so. It did not improve upon matter in any obvious way and the advent of mortality even suggested a deterioration; as Jonas observed, "If permanence was the point, life should not have started out in the first place, for in no possible form can it match the durability of inorganic bodies." 72 Yet this readily observed but profoundly puzzling phenomenon of biological evolution might hold the solution to the biggest riddle of all - the meaning of life-because this biological drive towards self-autonomy suggested that nature itself had a direction and a purpose (although not in the simplistic sense suggested by Teilhard de Chardin, for example). ${ }^{73}$ If the embeddedness and development of self-autonomy in organic matter was its real significance, Jonas now had a basic value intrinsic to life and that could function as the fundamental value around which an ethical system could be constructed. ${ }^{74}$ The direction of nature was to be considered an objective good-in-itself and something with which one ought to align oneself ethically. ${ }^{75}$ For Jonas, it followed that there was an obligation to preserve the continuity of the human species - what he called the "imperative of responsibility" - because the human capacity for self-autonomy was the outcome of an evolutionary process that had bestowed nature with a purpose. Holding freedom and selfhood sacred allowed one to establish them as the basic criteria by which one might relate to other humans - and not only other humans. In contrast

70 Hans Jonas, “Tool, Image and Grave: On What is Beyond the Animal in Man," pp. 75-86 in Jonas and Vogel, Mortality and Morality, on pp. 78-84; first published as Hans Jonas, "Werkzeug, Bild und Grab: Vom Transanimalischen im Menschen," Scheidewege 15 (1985-6): 47-58

71 Jonas, "Evolution and Freedom," p. 63

72 Hans Jonas, "Immortality and the Modern Temper," pp. 115-130 in Jonas and Vogel, Mortality and Morality, on p. 126; first published as Hans Jonas, "Immortality and the Modern Temper," Harvard Theological Review 55 (1962): 1-20.

73 Jonas, The Phenomenon of Life, p. xxiv.

74 Jonas and Herr, The Imperative of Responsibility, pp. 81-82.

75 Ibid., pp. 34-50. 
with Kaplan, Jonas' theory had radical implications for other kinds of life, which manifested the same characteristics, albeit in less developed form, and even for the natural environment, since matter was potential life, according to this perspective, a kind of life-in-waiting. ${ }^{76}$

This is the way, then, that Jonas sought to offer an ethical worldview that was compatible with and complementary to the science of biology, or, more accurately, to a philosophical interpretation of metabolism and Darwinian theory. (One of his students, Donnelly, argues that Jonas was not actually familiar with some of the key aspects of Darwinian theory in that he made "rather sparing use" of Darwinian biology, specifically in relation to the role of genetic information in evolution and to the historical character of natural history, in which biotic and abiotic co-evolvement has been a major feature. ${ }^{77}$ It was, as should be clear, an ethical "imperative of responsibility" that made no mention of religious tradition or transcendent authority. And yet, when Jonas brought his ideas together in his public lectures on immortality and on Auschwitz in the 1960s, he, like Kaplan, found himself using the language of theology and religious myth. Theology was, Jonas admitted, a "luxury of reason," 78 a highly speculative way of thinking about questions that lay beyond the reach of human knowledge. But as long as such musings on the unknowable did not contradict what was known through reason, he saw no harm in it. In fact, he argued that mythical truths could usefully complement philosophical truths, in that they spoke directly to human emotion rather than to human reason. ${ }^{79}$ An unconventional but avowedly religious Jew, ${ }^{80}$ Jonas drew heavily upon his understanding of Jewish tradition in the construction of this myth, which he revised several times.

The form in which the myth is presented here dates to a 1968 essay entitled "The Concept of God After Auschwitz: A Jewish Voice." It actually approaches the Holocaust somewhat tangentially, in that Jonas' first concern is to consider the nature of God's interaction with His creation. ${ }^{81} \mathrm{He}$ envisions a God who, in the beginning and for unknowable reasons, had committed Himself to a cosmic experiment in "chance and risk and [the] endless variety of becoming." 82 This God, who contained the cosmos but was not to be identified with it, as is made explicit in an earlier version, ${ }^{83}$ had created it by establishing the physical and biological laws that unfolded over time and space without

76 Jonas, "Evolution und Freedom," p. 62. For Jonas' contribution to Jewish environmental ethics, see Lawrence Troster, "Caretaker or Citizen? Hans Jonas, Aldo Leopold and the Development of Jewish Environmental Ethics," pp. 373-396 in The Legacy of Hans Jonas: Judaism and the Phenomenon of Life, ed. Hava TiroshSamuelson and Christian Wiese (Leiden: Brill, 2010).

77 Strachan Donnelley, "Hans Jonas and Ernst Mayr," pp. 261-285 in The Legacy of Hans Jonas, ed. Tirosh-Samuelson and Wiese, on pp. 273-274.

78 Jonas and Vogel, Mortality and Morality, p. 113 (section heading).

79 Jonas and Herr, The Imperative of Responsibility, p. 85.

80 Hans Jonas, Rachel Salamander, and Christian Wiese, Erinnerungen (Frankfurt am Main: Suhrkamp, 2003), pp. 339-41. See also Christian Wiese, “'God's Adventure with the World' and 'Sanctity of Life'," pp. 419-460 in The Legacy of Hans Jonas, ed. Tirosh-Samuelson and Wiese, on pp. 420-421.

81 This myth was originally presented in its essential form as the 1961 Ingersoll Lecture at Harvard University and published as Jonas, "Immortality and the Modern Temper." While there are a few minor differences, the version of the myth used here is that in Hans Jonas, "The Concept of God after Auschwitz," pp. 465-487 in Out of the Whirlwind; a Reader of Holocaust Literature, ed. Albert H. Friedlander (New York: Union of American Hebrew Congregations, 1968). Vogel offers a useful study of how Jonas compares to other Jewish religious responses to the Shoah, including those of Rubenstein, Fackenheim, and Berkovits (Editor's Introduction in Jonas and Vogel, Mortality and Morality, pp. 30-36).

82 Jonas, "The Concept of God after Auschwitz," p. 465

83 Jonas, "Immortality and the Modern Temper," in Jonas and Vogel, Mortality and Morality, p. 125. 
any divine direction or correction and without foreknowledge of how it would develop. ${ }^{84}$ The cosmos was left to itself, to play out according to natural laws and probability, with God having withdrawn Himself completely from the process. ${ }^{85}$ Following the surprising emergence of life (described as "the world accident for which the becoming deity had waited"), ${ }^{86}$ blind evolutionary forces had eventually generated the human mind with its capacity for "knowledge and freedom," that is, for moral choice. The dead cosmos became the living cosmos, and the living cosmos became the moral cosmos. With the human, the organism had moved beyond existence-for-its-own-sake to existence-for-thesake-of-others, that is, an existence premised upon responsibility for others and for the cosmos itself, which had given birth to life and morality (as he puts it: "self-fulfilling life has given way to the charge of responsibility"). ${ }^{87}$ According to this account, God had found a partner in creation, in that the universe would no longer develop only according to the amoral natural laws by which $\mathrm{He}$ had established it, but could be radically altered by the self-aware, self-determined actions of humans, whether these deeds took place in ethical or material dimensions. To the extent that God was to be regarded as the ground of all being, containing the cosmos within Himself, those human deeds that shaped the world also affected God: "In the awesome impact of his deeds on God's destiny ... lies the immortality of man." 88

From this new myth there followed some interesting theological implications for any understanding of the divine, as Jonas himself observed. These included the idea of a "becoming God" who is profoundly affected by His creation, ${ }^{89}$ and in particular a suffering God who could be disappointed and hurt by His creation and his chosen people. ${ }^{90}$ Such a God confounds the traditional claim of omnipotence, since, for Jonas, the authentic act of creation must entail the selfrenunciation of the Creator's power; were God to intervene, He would be tampering with the process of free development and creation would not be truly free of and distinct from the Creator. Thus, while $\mathrm{He}$ remains in close relation with and cares for His creation, God has devolved responsibility for the creative process to humankind. ${ }^{91} \mathrm{By}$ the time Jonas arrives at a consideration of the Holocaust, he is able to explain God's silence at Auschwitz as the necessary consequence of the Creator's relation to His creation: "I entertain the idea of a God who for a time - the time of the ongoing world process - has divested Himself of any power to interfere with the physical course of things." 92 (Later, Jonas is more explicit still: "Not because he [God] chose to, but because he could not intervene did he fail to intervene." ${ }^{23}$ ) This means that the responsibility for the victimization of "the gassed and burnt children of Auschwitz" cannot lie with God but rather with humankind.

While by no means a classic statement of Jewish religion, ${ }^{94}$ this myth certainly resonates with familiar Jewish and biblical ideas. At its heart is a caring creator-God who is the ultimate source of both the universe and of life. ${ }^{95}$ Granted, Jonas' speculations about a suffering God and a "hidden God" might be thought to stray somewhat from

84 Jonas, “The Concept of God after Auschwitz," p. 466.

85 Ibid.

86 Ibid., pp. 466-467.

87 Ibid., p. 467.

88 Ibid.

89 Ibid.

90 Ibid., p. 468

91 Ibid., p. 470.

92 Ibid., p. 472

93 Hans Jonas, “The Concept of God After Auschwitz," pp. 131-143 in Jonas and Vogel, Mortality and Morality, on p. 140.

94 The Jewish aspects of his thought are considered at length in Wiese, The Life and Thought of Hans Jonas.

95 Jonas, “The Concept of God after Auschwitz,” p. 470. 
Jewish tradition, as he himself acknowledged. ${ }^{96}$ But he was quick to point out that such ideas were by no means foreign to Judaism. Biblical stories such as the Flood (Genesis 6-9) reminded us that the Hebrew God had rued the making of mankind; Hebrew prophets such as Hosea frequently expressed God's anguish at the failings of His Chosen People. ${ }^{97}$ In contrast to Hellenic associations of divinity with an eternal perfection, the Hebrew God was clearly affected by His world. ${ }^{98}$ Likewise, Jonas observed that his rejection of the conception of God as omnipotent, that is, his presentation of a God who could not interfere or intervene in the world after the moment of creation, could be expressed in the language of divine hiddenness. As such, it shared similarities with "the old Jewish idea" within the Lurianic Kabalistic tradition of tzimtzum or "contraction of the divine being as the condition for the being of a world." This was the mystical idea that God had created the world by an act of withdrawal, thereby making space for its independent existence, and that He must maintain this separation between the divine and nondivine in order for the world to go on. ${ }^{99}$ (Lazier points out that this idea of a deus absconditus is all the more surprising considering that Jonas' early career had been spent trying to demythologize "the gnostic stranger God," and notes with irony that "what began as a determined attempt to make [God] known ended with grateful praise for his absence." ${ }^{100}$ ) Furthermore, Jonas' solution to the problem of evil and Auschwitz-Auschwitz is contextualized with reference to Job's problem with suffering, in general, and the Jewish suffering as the chosen people, in particular-was explained by reference to the account in Genesis 1 of how God made man in His image, which Jonas interpreted to mean that God bestowed upon us the freedom to make ethical choices. ${ }^{101}$ An unfortunate consequence of this is that some will make evil choices that will bring great suffering upon the innocent, as had been horribly demonstrated by the Jewish Holocaust. Still, Jonas' myth should not be read as a simple expression of Jewish religiosity. After all, no Jewish thinker before Jonas had reached this theological position by means of, or at least by privileging, an evolutionary understanding of organic life.

How, then, does this myth relate to Jonas' much more extensive and developed philosophical reflections on the biology of life? To what extent is this simply a theological presentation of a naturalistic theory, as Bernstein has suggested ${ }^{102}$ Obviously, Jonas' vision of a transcendent creator-God who does not interfere in the development of the universe or life was not mentioned in his biological studies; quite the reverse: he assiduously avoided mention of God or theology. Yet there are deep connections. It is the assumptions behind the scientific method, the methodological commitment to natural rather than supernatural causes, that dictate the only kind of divinity that is compatible with his scientifically-informed philosophy, namely, a divinity who, in contrast to much of the Judeo-Christian tradition, cannot interfere in history and as such is not omnipotent. As Lazier observes, "this was a God relegated to the back seats of the cosmic theater he had built but could not direct." ${ }^{103}$ Again, he is keen to present the unfolding of the natural world and human history as a classical Darwinian process, that is, as open-ended and directionless. That said, the impression of the blind development of life presented in the myth actually appears to be in

96 Ibid., pp. 471-472.

97 Ibid., p. 468.

98 Ibid., pp. 468-469.

99 Ibid., p. 473.

100 Benjamin Lazier, God Interrupted: Heresy and the European Imagination between the World Wars (Princeton, NJ: Princeton University Press, 2008), p. 64.

101 Jonas, “The Concept of God after Auschwitz,” p. 473.

102 Richard J. Bernstein, Radical Evil: A Philosophical Interrogation (Cambridge: Polity, 2002), p. 200.

103 Lazier, God Interrupted, p. 60. 
tension with the idea, examined earlier, that biological evolution does in fact possess a direction. Certainly, there is no predestined goal in Jonas' philosophy, and by no means did any particular form of life-including human life-have to happen. In The Imperative of Responsibility and elsewhere he argued that humankind's existence was not preordained. Not only might it never have come about, but, with the technology of the twentieth century, it might well destroy itself; he was not optimistic in regard to the future of the human species. Yet there was also what he identified as a tendency or a yearning (a phenomenon he called "cosmogonic eros") 104 towards self-autonomy; in a sense, there was a certain inevitability about the continuing development of the freedom, subjectivity, and inner world of the evolving organism. The nearest Jonas came to articulating this tendency within his myth was the cryptic and brief aside that the emergence of humankind was the "world-accident" for which God had "waited."105 This is interesting because, historically speaking, the vast majority of evolutionary theists, whether Jewish or Christian, have tended to focus their efforts on identifying a direction within evolution of one sort or another and have presented it as evidence of divine action or intervention of one sort or another; it is a common means by which attempts are made to reconcile religion and evolutionary theory. As was discussed earlier, Kaplan went so far as to define the cosmic ordering principle which had led to the evolution of humanity as God. Jonas' apparent reluctance to make any such explicit connection between a direction in evolution and God may reflect a concern about undermining his majestic philosophy of biology by giving the impression that a naive religious belief lay behind it. (This may be true of Jonas' wider work in general. In relation to The Imperative of Responsibility, Wiese writes that the lack of religious language suggests that Jonas "wanted to avoid the risk of his project being branded a 'Jewish ethics' and thus having his influence impaired."106) It is unclear why he does not make such a connection. In any case, at the heart of his myth was an attempt to articulate, in nonphilosophical language, the ultimate value he gave to life and the struggle for selfautonomy. This ultimate value, along with its ethical implications, which he summarized as the "imperative of responsibility," might sound like a familiar set of religio-ethical concepts - and they certainly possess considerable emotive and rhetorical power when expressed in such religious language; but it is important to remember that he claimed to have derived them from reflection upon biology rather than from Scripture or religious tradition.

\section{Conclusion}

What have we learned from our comparison of the ways that Hans Jonas and Mordecai Kaplan engaged with evolutionary theory and the problem of evil and the Shoah, respectively?

One should not gloss over the dissimilarities between these two Jewish evolutionary theologies; there are at least three significant differences. First, only Kaplan offers a sustained critique of the social Darwinian ideology of the Nazis, which is seen to embody all that is wrong with the logic of natural selection as applied to human society. Second, only Kaplan was led by the implications of a proper

104 Jonas also discusses this tendency or characteristic of nature in terms of a "cosmogonic logos" (Jonas, "Matter, Mind and Creation,” p. 173). Margolin suggests that Jonas knew he had taken the term "cosmogonic eros" from a suspected antisemite, Ludwig Klages, but that he rejected Klages' understanding of the cosmic movement towards subjectivity as a negation of life and spirit and instead used it to express the idea of as a kind of will-in-matter that ultimately generated mind. See Ron Margolin, "Hans Jonas and Secular Religiosity," pp. 231-258 in The Legacy of Hans Jonas, ed. TiroshSamuelson and Wiese, on pp. 239-241.

105 Jonas, "The Concept of God after Auschwitz," p. 466.

106 Wiese, “'God's Adventure with the World' and 'Sanctity of Life',” p. 429 
understanding of the evolutionary nature of the universe to call for an institutional reform of Jewish religion and to justify this with an evolutionary rationale, setting out the historical stages of Judaism's organic development and defining religion as a driving force for spiritual selection. Third, only Jonas' mythical vision of a suffering, almost impotent God (whom at times he presented as capable of inspiration but certainly not of compulsion, and at other times identified in some sense with the emergence of human consciousness within the universe) represents an attempt to defend God against the charge of abandoning His people during the Shoah. In contrast, Kaplan refuses to offer any such theodicy or defense of God's justice, instead presenting a striking image of God as an impersonal evolutionary process; hence it makes no sense, as it might for Jonas, to speak of a free-will defense in Kaplan's theology, for there is no divine personality to defend.

Despite such differences, there are nevertheless some very interesting similarities between them, not least the fact that they appear to be alone among Jewish thinkers in attempting to offer religious responses to the Auschwitz that follow on from their applications of evolutionary theory to Judaism; perhaps as a result of this, neither was interested in engaging directly with other Jewish post-Holocaust theologies. For Jonas, a God conceived much in the fashion that deists conceive of him initiated the laws of evolution, which brought about the world, life, and the "surprising" advent of a moral animal. The open-ended, evolving universe had generated order out of disorder and had eventually given rise to life (characterized by a striving toward freedom and selfhood), which could be perceived as a good-in-itself and thus suffused the universe with meaning. His ethical solution, his "imperative to responsibility," draws in not only humans but also all other forms of life and even the inanimate world or environment. This is effectively where the influence of evolution ends in Jonas' thought: evil is the result of moral choice; the evil of the Shoah is entirely the result of human action, even if it is expressed as a wound inflicted upon the deity.
For Kaplan, too, the meaning of life is to be located in the natural world and evolutionary theory, although in his case by identifying a direction away from disorder and towards order, rather than a tendency toward greater freedom and selfhood. So both men begin by thinking about the way in which order, and eventually life itself, is brought about in a chaotic universe through evolutionary processes, and both suggest that this observation has profound implications for human morality. This is why both have been linked to Process Theology. ${ }^{107}$ (Lubarsky, who regards Jonas as a "process philosopher," suggests that he came to read the preeminent process philosopher, Alfred Whitehead, too late to solve two key problems in his own theory, namely: "how to avoid psycho-physical dualism; and, theologically, how to conceive of God as a non-supernatural yet efficacious agent in the world." ${ }^{108}$ ) Crucially, both attempt to align their ethical systems with the purposeful direction that they identify in nature (although Kaplan's ethics retains an exclusively human focus, in contrast to Jonas' wider concerns for animal life and the environment). The Holocaust, for Kaplan as for Jonas, is to be conceived of as an instance of the problem of evil, rather than as an unprecedented event with unique theological or historical consequences. ${ }^{109}$ Kaplan's explanation for it also depends on human free-will, but for Kaplan mankind's will is free only in potentia, because it is constrained and limited by evolutionary pressures (both natural

107 For Kaplan, see William E. Kaufman, "Mordecai M. Kaplan and Process Theology: Metaphysical and Pragmatic Perspectives,” Process Studies 20(4) (1991): 192-203. For Jonas, see Wiese, “'God's Adventure with the World' and 'Sanctity of Life'," p. 444.

108 Sandra B. Lubarsky, "Jonas, Whitehead, and the Problem of Power," pp. 397-417 in The Legacy of Hans Jonas, ed. Tirosh-Samuelson and Wiese.

109 For a discussion of some Jewish religious responses that make unique claims for the Holocaust, see Daniel R. Langton, "God, the Past and Auschwitz: Jewish Holocaust Theologians' Engagement with History,” Holocaust Studies 17(1) (2012): 29-62. 
selection and "spiritual selection") that work on the soul of man. Such imbalance, such disorder, is built into the very structure of the universe. So it is worth pointing out that, unlike Jonas, Kaplan regards the Holocaust as more than merely a case of human moral failure. Again, both men offer an understanding of God that challenges the traditional conception of an omnipotent deity and that emphasizes the human-divine partnership, albeit in different ways. Kaplan portrays God as a kind of impersonal process and offers an optimistic vision of the direction of human evolution as constrained only by the limits of human creativity, with the history of group religion and "spiritual selection" boding well for the future. Jonas' more personal but selflimiting God has in effect abandoned the future ethical and material development of the world, leaving it in the hands of humanity (even as $\mathrm{He}$ cares for our fate and suffers with us), a prospect about which he is more fearful. Finally, there is a shared conviction that the religionscience debate has left Jewish tradition and its ethical teachings enriched by the insights offered from evolutionary theory and that new ways must be found to express the relationship between theology and science. Kaplan expresses his worldview in the language of transnaturalism, that is, in a language that tries to transcend naturalistic and supernatural conceptions of reality. Jonas' attempts something slightly different, in that he offers both a naturalistic and a mythical account of reality in order to do his worldview justice. But neither accepts the stark choice of either a purely materialistic conception of the world or a purely idealistic one. 